\title{
Is it reasonable to ignore vitamin D status for musculoskeletal health?
}

\author{
Rebecca S. Mason ${ }^{1 *}$ Mark S. Rybchyn ${ }^{1} \quad$ Tara C. Brennan-Speranza ${ }^{1,2} \quad$ David R. Fraser ${ }^{3}$ \\ ${ }^{1}$ Physiology, Bosch Institute, School of Medical Sciences, Faculty of Medicine and Health, University of Sydney, Sydney, NSW, 2006, Australia \\ ${ }^{2}$ School of Public Health, Faculty of Medicine and Health, University of Sydney, Sydney, NSW, 2006, Australia \\ ${ }^{3}$ Sydney School of Veterinary Science, Faculty of Science, The University of Sydney, NSW 2006, Australia
}

\begin{abstract}
Severe vitamin D deficiency — 25-hydroxyvitamin D (25OHD) concentrations below around 25-30 nmol/L—may lead to growth plate disorganization and mineralization abnormalities in children (rickets) and mineralization defects throughout the skeleton (osteomalacia) and proximal muscle weakness. Both problems are reversed with vitamin D treatment. Apart from this musculoskeletal dysfunction at very low vitamin D levels, there is apparent inconsistency in the available data about whether concentrations of $25 \mathrm{OHD}$ below around $50 \mathrm{nmol} / \mathrm{L}$ cause muscle function impairment and increase the risk of fracture. This narrative review provides evidence to support the contention that improving vitamin D status, up to around $50 \mathrm{nmol} / \mathrm{L}$, plays a small causal role in optimizing bone and muscle function as well as reducing overall mortality.
\end{abstract}

\section{Keywords}

Vitamin D status; 25-hydroxyvitamin D, bone, muscle, parathyroid hormone, calcium, phosphate

\section{Peer Review}

The peer reviewers who approve this article are:

1. Michael A. Levine, Department of Pediatrics, University of Pennsylvania Perelman School of Medicine and The Children's Hospital of Philadelphia, Philadelphia, PA, USA

Competing interests: No competing interests were disclosed.

2. Ian R. Reid, Department of Medicine, Faculty of Medical and Health Sciences, University of Auckland, Auckland, New Zealand

Competing interests: No competing interests were disclosed. 
*Corresponding authors: Rebecca S. Mason (rebecca.mason@sydney.edu.au)

Competing interests: The authors declare that they have no competing interests.

Grant information: This work was supported by a grant from the Australian Research Council DP170104408.

The funders had no role in study design, data collection and analysis, decision to publish, or preparation of the manuscript.

Copyright: (C) 2020 Mason RS et al. This is an open access article distributed under the terms of the Creative Commons Attribution License, which permits unrestricted use, distribution, and reproduction in any medium, provided the original work is properly cited.

How to cite this article: Mason RS, Rybchyn MS, Brennan-Speranza TC and Fraser DR. Is it reasonable to ignore vitamin D status for musculoskeletal health? Faculty Reviews 2020 9:(19) https://doi.org/10.12703/r/9-19

Published: 03 Dec 2020, Faculty Reviews 9:(19) https://doi.org/10.12703/r/9-19 


\section{Introduction}

Over the past few years, one might be forgiven for holding the impression that vitamin D status is of little consequence for musculoskeletal function or much else ${ }^{1-4}$. This impression would be in distinct contrast to the view prevalent around 10 years ago that vitamin D is critical for almost every physiological function ${ }^{5}$. What follows is not a systematic review but an attempt to examine the role of the vitamin $\mathrm{D}$ system in bone and muscle function in light of older as well as more recent evidence.

\section{Physiology of vitamin D}

Although mistakenly called a vitamin, vitamin $\mathrm{D}$ is really obtained by the action of ultraviolet light on skin, which opens the B-ring of 7-dehydrocholesterol to produce pre-vitamin D. At body temperature, pre-vitamin $\mathrm{D}$ converts to vitamin $\mathrm{D} 3$, also known as cholecalciferol ${ }^{6}$. Vitamin D3 or the fungal or yeastderived vitamin D2/ergocalciferol ${ }^{7}$ may also be ingested through diet, though most unfortified foods contain very little vitamin $\mathrm{D}^{8,9}$. Vitamin $\mathrm{D}$ is converted in the liver, primarily, into 25-hydroxyvitamin D (25OHD), the major circulating metabolite with a long half-life ${ }^{10}$, which is in turn converted in the kidney, predominantly, into the active hormone 1,25-dihydroxyvitamin $\mathrm{D}-1,25(\mathrm{OH}) 2 \mathrm{D}$, also known as calcitriol-which appears in the circulation. Both 25-hydroxylation and $1 \alpha$-hydroxylation also occur in many other tissues but with the resultant hormone mainly available for use only by local cells ${ }^{11,12}$. Vitamin D status is measured by the concentration of the major circulating vitamin D metabolite, 25OHD, and not by concentrations of vitamin $\mathrm{D}$ itself or the hormone made from vitamin $\mathrm{D}, 1,25(\mathrm{OH}) 2 \mathrm{D}^{13-15}$.

There is little doubt that vitamin D plays a key role, along with calcium intake, in underpinning bone and muscle function. At blood concentrations of $25 \mathrm{OHD}$ below around $30 \mathrm{nmol} / \mathrm{L}$, there is a risk of developing rickets (impaired growth plate dynamics), osteomalacia (undermineralization of bone matrix/ osteoid), and muscle weakness, particularly affecting proximal muscles ${ }^{15,16}$. All of these signs are ameliorated by treatment with vitamin $\mathrm{D}^{15,16}$. Severe calcium deficiency can also cause rickets ${ }^{17}$. $1,25(\mathrm{OH}) 2 \mathrm{D}$ increases active intestinal absorption of calcium, provided there is ingested calcium to absorb. Calcium is not abundant in the diets of land-dwelling animals but is required for mineralization of new or replacement bone matrix and is important for many signaling processes in cells, including muscle contraction and relaxation as well as skeletal muscle development, growth, and regeneration ${ }^{18}$. Because of obligatory losses of calcium in urine and other waste, maintenance of calcium homeostasis is a constant issue for humans and other land-dwelling vertebrates ${ }^{19}$.

Without adequate vitamin $\mathrm{D}$ and/or calcium, parathyroid hormone $(\mathrm{PTH})$ secretion increases. While PTH drives renal production of $1,25(\mathrm{OH}) 2 \mathrm{D}$, reduces urinary calcium losses, and mobilizes bone resorption as an alternative source of calcium to maintain blood and extracellular calcium concentrations, it also drives urinary phosphorus excretion, reducing available phosphate. It is the reduction in phosphate, in particular, which appears to underpin the growth plate disorganization, in part due to impaired chondrocyte apoptosis ${ }^{20}$, that manifests as rickets. These actions of PTH may not be enough to maintain serum calcium concentrations under the circumstances. Impaired mineralization appears to be mostly a function of inadequate calcium and phosphorus availability, as these are the key minerals which make up the hydroxyapatite crystal of bone mineral. The relative importance of direct actions of 1,25(OH)2D in bone, especially considering that it is produced locally in this tissue $^{15}$, is unclear, but two studies of calcium-deficiency rickets reported that vitamin D and calcium supplementation improved rickets in a larger proportion of children than calcium alone $^{21}$, despite the already high gut calcium absorption rates in the children at baseline ${ }^{17}$.

\section{Vitamin D and muscle function}

The underlying pathophysiology of muscle weakness in vitamin D deficiency is also not settled ${ }^{22}$. Vitamin D compounds affect skeletal muscle development and regeneration ${ }^{23,24}$. Whether this is direct or indirect is unclear, but there is some evidence that phosphorus deficiency may, at least in part, contribute ${ }^{25}$. Hypophosphatemic individuals display proximal muscle weakness $^{26}$. Secondary hyperparathyroidism has also been postulated as a mechanism, since proximal muscle weakness is a recognized feature of primary hyperparathyroidism ${ }^{27}$. Other mechanisms have also been proposed. Impaired calcium signaling or changes in calcium fluxes in muscle cells contribute to the mechanism of muscle weakness in vitamin D deficiency ${ }^{16,28-30}$, potentially through impairment of calcium uptake into the endoplasmic/sarcoplasmic reticulum. Reductions in sarcoplasmic/ endoplasmic reticulum ATPase (SERCA) proteins and calbindin have been reported in mice with myocyte knockout of the vitamin D receptor $(\mathrm{VDR})^{31}$. Vitamin D treatment also improved mitochondrial oxidative phosphorylation in skeletal muscle in patients with severe vitamin D deficiency ${ }^{32}$. It is difficult to explain rapid subjective improvement of muscle weakness in severely vitamin D-deficient people, within 24 hours of an oral dose of vitamin $\mathrm{D}$, in terms of correction of secondary hyperparathyroidism and hypophosphatemia.

The question of how important direct actions of $1,25(\mathrm{OH}) 2 \mathrm{D}$ or other vitamin D metabolites are for muscle function remains unanswered. Despite some controversy about whether VDRs are present in mature fresh muscle ${ }^{33,34}$, the current evidence indicates that they are found in mouse and human muscle tissue $^{35-38}$, although at very much reduced levels compared with VDR levels in the intestine ${ }^{35}$. Mice with myocyte knockout of the VDR have low muscle mass and show reduced voluntary activity $^{31,39}$, indicating at least a role for the VDR in muscle development. In a recent systematic review of genetic associations with aging muscle, polymorphisms in VDR were featured, with the highest number of studies carried out on this gene $^{40}$, though even that review did not include all possible papers on the subject. As frequently noted in the literature, different studies have found different associations with particular polymorphisms of the VDR. In general, muscle function in older populations, variously measured, has been linked mostly to polymorphisms in Fok1 and Bsm1. The Fok1 site in exon 
2 affects the translation initiation site ${ }^{41}$. The "f" allele denotes a start site for the VDR that results in a full-length VDR, whereas the "F" allele, which appears to be more transcriptionally active, codes for a later start site and a protein that is three amino acids shorter $^{41}$. Most studies indicate a link between the presence of the "F" allele and worse muscle performance and/or sarcopenia $^{42-47}$, but other studies showed no relationship ${ }^{48}$ or even a reverse association ${ }^{49}$. Polymorphisms in the Bsm1 allele in the 3'-untranslated region appear to affect mRNA stability of $\mathrm{VDR}^{50,51}$. The associations between either allele of Bsm1 and muscle strength/sarcopenia seem weaker and more variable than those for Fok $1^{40,45,47,48}$. These studies were all carried out in older individuals with all the limitations of that approach. One study of 700 primary school children in Hungary found a strong association between highly heritable hand grip strength in both dominant and non-dominant hands with the $A 1012 G$ (rs45160335) polymorphism in the $1 \mathrm{e}$ promoter region at the 5 ' part of the gene $^{52}$. The presence of VDR in muscle cells has recently been shown to be critical for mitochondrial function ${ }^{53}$, and numerous VDR promoter elements in mitochondrial DNA have been described $^{54}$. Observational studies indicate that muscle VDRs decrease with age $\mathrm{e}^{55}$ and have been reported to increase with modest vitamin D supplementation in older women ${ }^{56}$.

Whether the problems of rickets and/or osteomalacia and proximal muscle weakness are entirely due to abnormal calcium or phosphate homeostasis has been examined in pre-clinical models. In mouse models, the rickets, osteomalacia, muscle weakness, and secondary hyperparathyroidism observed in mice with global knockout of the VDR is largely, if not entirely ${ }^{57}$, reversed by feeding the mice a rescue diet of increased calcium and phosphorus, together with high lactose, which appears to facilitate calcium absorption ${ }^{58}$, or by engineering VDR expression just in the intestine ${ }^{59}$. Apart from rickets and osteomalacia, high PTH concentrations, which may occur secondary to vitamin D deficiency, are associated with increased cortical bone porosity and associated increased risk of fracture ${ }^{60,61}$. In human patients with VDR mutations that impair function, calcium infusions coupled with high-calcium diets appear to allow for growth and mineralization through childhood ${ }^{62}$. For reasons that are not clear, once these affected patients reach maturity and so are only replacing bone being remodeled and not growing a skeleton, very high calcium intakes are no longer required, as calcium absorption is increased by non-VDR mechanisms, thus relieving the secondary hyperparathyroidism and associated hypophosphatemia ${ }^{62}$. These patients seem to have relatively normal bone in adulthood and are able to lead a relatively normal life, including having children ${ }^{62,63}$.

These observations tend to support the proposal that the key musculoskeletal action of the vitamin D system is to enhance gut calcium absorption and so prevent the secondary hyperparathyroidism and resultant urinary phosphorus losses ${ }^{15}$.

Proximal muscle weakness is a hallmark of vitamin D deficiency at all ages ${ }^{30}$. Vitamin D status is a predictor of muscle function across adult age groups ${ }^{64}$, particularly in older individuals ${ }^{65}$, and may even predict loss of muscle mass and falls in older people ${ }^{66,67}$. Even so, since there is evidence that muscle, like other tissues, expresses both 25-hydroxylase and $1 \alpha$-hydroxylase ${ }^{68,69}$, an association between vitamin $\mathrm{D}$ status, as measured by circulating $25(\mathrm{OH}) \mathrm{D}$, and muscle function may not be apparent under some circumstances. Declines in muscle function, particularly in older people, are observed below $25 \mathrm{OHD}$ concentrations of $40-60 \mathrm{nmol} / \mathrm{L}^{64,65}$. Older studies in students showed improvements in muscle performance after exposure to ultraviolet light ${ }^{70}$. In athletes, who, as a group, have a rather low vitamin D status ${ }^{71}$, supplementation with vitamin D has produced variable responses, even in studies from the same group $^{72,73}$. A recent meta-analysis showed no overall improvement in athletic performance with vitamin D supplements ${ }^{74-76}$. In non-athletes, vitamin D supplementation studies have also produced mixed results ${ }^{74,77-79}$ (reviewed in 16 and 80). Benefits of vitamin D supplementation have mainly been reported in people with severe vitamin $\mathrm{D}$ deficiency, such as veiled women with a mean $25 \mathrm{OHD}$ concentration around $7 \mathrm{nmol} / \mathrm{L}^{81}$, in studies where vitamin $\mathrm{D}$ was given with calcium ${ }^{82}$, where doses of 800-1,000 IU/day were used $^{83}$, and in older individuals with baseline $25 \mathrm{OHD}$ concentration below 25 or $30 \mathrm{nmol} / \mathrm{L}^{84-86}$.

\section{Vitamin D and bone}

In relation to bone density, based on large-scale observational data, there is a positive correlation between 25OHD concentrations and bone density. In two major studies, one in younger and older adults and the other in older people, bone mineral density increased with increasing $25 \mathrm{OHD}$ but reached a plateau at around $50-60 \mathrm{nmol} / \mathrm{L}^{87,88}$. The effects of higher vitamin D status on bone density are relatively small ${ }^{87-89}$, much smaller than the effects of age, for example ${ }^{90}$. In a number of randomized controlled trials (RCTs) of older individuals, supplementation with vitamin $\mathrm{D}$ alone has been reported to have no effect or a small positive effect on bone mineral density ${ }^{91}$, but vitamin D supplements with calcium had relatively small positive effects on bone mineral density ${ }^{92,93}$, with significant effects mostly seen in those with $25 \mathrm{OHD}$ levels below $30-40 \mathrm{nmol} / \mathrm{L}$ at baseline ${ }^{94}$.

Increased osteoid (unmineralized bone matrix) of $>5 \%$ bone volume is a hallmark of severe vitamin $\mathrm{D}$ and/or calcium deficiency ${ }^{95}$ but was reported in only $10 \%$ of hip fracture patients with a $25 \mathrm{OHD}$ of $<30 \mathrm{nmol} / \mathrm{L}^{96}$. One German study of postmortem samples of blood and bone after acute trauma found no evidence of osteomalacia/excess osteoid ( $>5 \%)$ provided subjects had blood $25 \mathrm{OHD}$ concentrations above $50 \mathrm{nmol} / \mathrm{L}^{97}$. Interestingly, the taskforce for the Endocrine Society USA used the same data to support the case for a $75 \mathrm{nmol} / \mathrm{L}$ target for $25 \mathrm{OHD}$ by classifying abnormal osteoid at $>2 \%$ rather than $>5 \%$.

It might be argued from the above data that even moderate degrees of vitamin D deficiency should cause musculoskeletal dysfunction with increased risks of falls, due to muscle weakness and/or impaired coordination, and fractures. These associations have certainly been reported ${ }^{15}$. The risk of falls and fractures in young people is relatively low, so most RCTs tend to be done in older populations. If low vitamin D status increases the risk of falls and fractures, replacement of vitamin D in these 
moderately deficient subjects should reduce these events. But that is not the consistent outcome of RCTs.

Results of RCTs of vitamin D supplements, often with calcium, have been variable for falls ${ }^{99-103}$. Overall, though, these studies showed a modest, around $15 \%$, reduction in the risk of falls ${ }^{103}$, or of fallers, mostly when supplements of more than 700 IU were given ${ }^{99}$ (this dose is likely to raise 25OHD above $50 \mathrm{nmol} / \mathrm{L}$ ) along with adequate calcium intake or supplemental calcium $^{104}$ and when the target population was in institutionalized care, with low vitamin D status ${ }^{100}$ or ambulatory 25OHD values below $50 \mathrm{nmol} / \mathrm{L}^{101}$.

A recent meta-analysis of RCTs of vitamin D supplements to reduce fracture risk reported that supplementation with vitamin $\mathrm{D}$ alone did not affect fracture incidence but supplementation with vitamin D and calcium reduced fractures significantly ${ }^{105}$. This has been reported before in a Cochrane review ${ }^{106-108}$. Even so, most of these meta-analyses (reviewed ${ }^{1,15,109}$ ) indicate an overall small reduction in fractures with vitamin $\mathrm{D}$ and calcium together, with more benefit seen in patients at higher risk of fracture and those given at least $800 \mathrm{IU}$ of vitamin D a day. That dose of vitamin D would be expected to increase blood 25OHD concentration to above $50 \mathrm{nmol} / \mathrm{L}^{110}$. Although this small reduction in fracture risk of around $15 \%$ has been described as unimportant by some $^{1,111}$, this is unlikely to be the view of most patients at risk or the health system that pays for the immediate and long-term costs.

These results, which overall indicate that supplementation with both vitamin $\mathrm{D}$ and calcium is needed to reduce fracture risk to at least a small extent and mainly in susceptible populations, are perhaps not entirely surprising. If the main effect of adequate vitamin D status is to increase the absorption of gut calcium, it ought to help if calcium intake is also adequate. In many older people, it is not. Analyses which specifically exclude those studies in which vitamin D and calcium were given are thus more likely to report outcomes of no effect from vitamin D supplementation ${ }^{105}$. Indeed, when high doses of vitamin $\mathrm{D}$ have been given intermittently, increased falls and fractures have been reported ${ }^{112,113}$. Then there are other considerations. Vitamin D has been described as a "threshold nutrient"15: if people have enough vitamin D (25OHD), giving more is not likely to make much difference. In many RCTs, the mean or median vitamin $\mathrm{D}$ status of participants, measured by $25(\mathrm{OH}) \mathrm{D}$ at baseline, is well above any reasonable threshold of $30 \mathrm{nmol} / \mathrm{L}^{14,15}$ or $50 \mathrm{nmol} / \mathrm{L}^{107,114}$. Some studies specify analysis of subgroups deemed low in vitamin $\mathrm{D}$, but numbers are necessarily lower than in the main group, especially in studies in North America, where food fortification with vitamin D is extensive ${ }^{8,9}$.

\section{Vitamin D and mortality}

The hormonal form of vitamin $\mathrm{D}, 1,25(\mathrm{OH}) 2 \mathrm{D}$, when bound to its receptor, affects the transcription of hundreds of genes ${ }^{115}$. Not surprisingly, low vitamin D status, however defined, has been linked with increased risks of a range of health issues, such as increased inflammation, increased risk of some autoimmune conditions, increased risk of some cancers, poor sleep, poorer outcomes of pregnancy, increased risk of type 2 diabetes, and increased overall mortality. While there are problems with the design and/or implementation of many RCTs for vitamin $\mathrm{D}^{116}$, the frequently negative results for non-musculoskeletal outcomes have led to the argument that low vitamin $\mathrm{D}$ status is mainly a marker of poor health, which may indeed be the case ${ }^{117}$. Two recent meta-analyses of RCTs for the prevention of acute respiratory infection or reducing exacerbations of asthma requiring corticosteroid treatment found a small benefit overall with daily or weekly vitamin D supplements, but the benefit was most pronounced in individuals with $25 \mathrm{OHD}$ concentrations below $25 \mathrm{nmol} / \mathrm{L}$ at baseline ${ }^{118,119}$.

There is a clear association between low vitamin D status and increased age-adjusted mortality. Two observational studies involving a quarter of a million Danes and 15,000 people from the NHANES cohort showed an increased risk of death over 5-6 years in people with a baseline 25OHD level below approximately $50 \mathrm{nmol} / \mathrm{L}^{120}$ or $40-75 \mathrm{nmol} / \mathrm{L}$ depending on sex $^{121}$. Elevated PTH levels, even within the normal range, are known to increase risk of mortality ${ }^{120,122}$. With some exceptions ${ }^{1}$, meta-analyses of RCTs of vitamin D mostly with calcium supplementation, which recorded mortality as a safety endpoint rather than the primary outcome, indicated that supplementation reduced mortality in the treatment groups in older individuals with a mean $25 \mathrm{OHD}$ level of approximately $37 \mathrm{nmol} / \mathrm{L}$ at baseline by $6-11 \%^{123-125}$.

\section{Issues with RCTs of vitamin D}

There are many further caveats to the use of RCTs as a means of demonstrating causality in relation to the associations between vitamin D status and musculoskeletal or other health parameters. Most studies of vitamin D supplementation with or without calcium have used white Caucasian subjects. The target optimal 25OHD concentration to be achieved in non-whites is not as clear and may be lower in some groups ${ }^{126}$. Assays for 25OHD are relatively variable compared to other hormone assays ${ }^{14,116,127}$. It must also be kept in mind that some people with $25 \mathrm{OHD}$ concentrations below $30 \mathrm{nmol} / \mathrm{L}$ may have little evidence of biochemical or musculoskeletal abnormalities ${ }^{2}$. Furthermore, once 25OHD blood concentrations are above 25-30 nmol/L or so, the observed effects of vitamin D status on many functions are small compared with other more major factors, like sex steroids and age on bone mass, age and exercise on muscle mass, carcinogens or lifestyle factors and genetic influences on cancer and cardiovascular disease, and thus overall mortality.

If one looks at vitamin D status at various ages in a developed western country like Australia, some interesting patterns emerge. In a very large Australian Bureau of Statistics study of approximately 10,000 people from the electoral roll with 25OHD analysis by liquid chromatography mass spectroscopy, it was those aged 18-34 who had the highest prevalence of vitamin $\mathrm{D}$ deficiency ${ }^{128}$. At these ages, people spend a lot of time inside, for entertainment, raising children, and working. 
It seems younger children are less at risk of low vitamin D status, but there is more of a problem in the teen years. People in the early pre-retirement or retirement years, aged 60-74 years, also had better vitamin $\mathrm{D}$ levels, whether because of more supplementation awareness or more leisure time ${ }^{128}$. In the younger and middle years, when bone and muscle mass and function are relatively high, the risks of falls, fractures, or death are relatively low and very much less likely to be greatly affected by vitamin D status. But prudence suggests that it is probably better to maintain target vitamin D levels, even during this period of life, to help provide a better baseline for life in more advanced years ${ }^{65}$.

\section{Conclusions}

There is fairly uniform evidence and agreement that 25OHD levels below 25-30 nmol/L are likely to be detrimental to musculoskeletal health, especially if calcium intake is not optimal. A potential unifying hypothesis is that low vitamin D status, especially with low calcium intake, results in a tendency to negative calcium balance and a secondary increase in PTH concentrations, which cause renal phosphate wasting and hypophosphatemia. The low available calcium, low phosphate, elevated PTH, and/or low vitamin D impair muscle function and repair, leading to proximal muscle weakness. The low phosphate interferes with chondrocyte maturation at the growth plate (rickets) and, together with relatively low calcium, reduces mineralization of osteoid (osteomalacia) while the increased PTH increases bone resorption, resulting in cortical bone porosity and increased fracture risk. If elevated PTH is part of the problem, it is not surprising that supplying both vitamin D and calcium diminishes the problem. At a younger age, none of this may matter greatly. Most interpretations of meta-analyses of RCTs in older individuals tend to support the proposal that improving vitamin $\mathrm{D}$ status, up to around $50 \mathrm{nmol} / \mathrm{L}$, plays a small causal role in optimizing bone and muscle function as well as reducing overall mortality.
1. Bolland MJ, Grey A, Gamble GD, et al.: The effect of vitamin D supplementation on skeletal, vascular, or cancer outcomes: a trial sequential meta-analysis. Lancet Diabetes Endocrinol. 2014; 2(4): 307-20.

PubMed Abstract | Publisher Full Text

2. Shah S, Chiang C, Sikaris K, et al:: Serum 25-Hydroxyvitamin D Insufficiency in Search of a Bone Disease. J Clin Endocrinol Metab. 2017; 102(7): 2321-8. PubMed Abstract | Publisher Full Text

3. Reid IR, Bolland MJ: Calcium and/or Vitamin D Supplementation for the Prevention of Fragility Fractures: Who Needs It? Nutrients. 2020; 12(4): 1011 PubMed Abstract | Publisher Full Text | Free Full Text | Faculty Opinions Recommendation

4. LeBoff MS, Murata EM, Cook NR, et al.: VITamin D and OmegA-3 TriaL (VITAL): Effects of Vitamin D Supplements on Risk of Falls in the US Population. J Clin Endocrinol Metab. 2020; 105(9): 2929-2938. PubMed Abstract | Publisher Full Text | Free Full Text | Faculty Opinions Recommendation

5. Holick MF: Vitamin D deficiency. N Engl J Med. 2007; 357(3): 266-81. PubMed Abstract | Publisher Full Text | Faculty Opinions Recommendation

6. Holick MF: The cutaneous photosynthesis of previtamin D3: a unique photoendocrine system. J Invest Dermatol. 1981; 77(1): 51-8. PubMed Abstract | Publisher Full Text

7. Dupont S, Lemetais G, Ferreira T, et al.: Ergosterol biosynthesis: a fungal pathway for life on land? Evolution. 2012; 66(9): 2961-8. PubMed Abstract | Publisher Full Text

8. Norman AW, Bouillon R: Vitamin D nutritional policy needs a vision for the future. Exp Biol Med (Maywood). 2010; 235(9): 1034-45. PubMed Abstract | Publisher Full Text

9. Itkonen ST, Erkkola M, Lamberg-Allardt CJE: Vitamin D Fortification of Fluid Milk Products and Their Contribution to Vitamin D Intake and Vitamin D Status in Observational Studies-A Review. Nutrients. 2018; 10(8): 1054 PubMed Abstract | Publisher Full Text | Free Full Text | Faculty Opinions Recommendation

10. Clements MR, Davies M, Fraser DR, et al:: Metabolic inactivation of vitamin D is enhanced in primary hyperparathyroidism. Clin Sci (Lond). 1987; 73(6): 659-64. PubMed Abstract | Publisher Full Text

11. Pryke AM, Duggan $C$, White $\mathrm{CP}$, et al:: Tumor necrosis factor-alpha induces vitamin $\mathrm{D}$-1-hydroxylase activity in normal human alveolar macrophages. J Cell Physiol. 1990; 142(3): 652-6.

PubMed Abstract | Publisher Full Text

12. Lehmann B, Sauter W, Knuschke $\mathrm{P}$, et al.: Demonstration of UVB-induced synthesis of 1 alpha,25-dihydroxyvitamin $D_{3}$ (calcitriol) in human skin by microdialysis. Arch Dermatol Res. 2003; 295(1): 24-8.

PubMed Abstract | Publisher Full Text

13. Mason RS: Vitamin D: a hormone for all seasons. Climacteric. 2011; 14(2): 197-203.

PubMed Abstract | Publisher Full Text

14. Sempos CT, Heijboer AC, Bikle DD, et al.: Vitamin D assays and the definition of hypovitaminosis D: results from the First International Conference on Controversies in Vitamin D. Br J Clin Pharmacol. 2018; 84(10): 2194-207.

PubMed Abstract | Publisher Full Text | Free Full Text | Faculty Opinions Recommendation

15. Bouillon R, Marcocci C, Carmeliet G, et al:: Skeletal and Extraskeletal Actions of Vitamin D: Current Evidence and Outstanding Questions. Endocr Rev. 2019; 40(4): 1109-51.

PubMed Abstract | Publisher Full Text | Free Full Text | Faculty Opinions Recommendation

16. Gunton JE, Girgis CM: Vitamin D and muscle. Bone Rep. 2018; 8: 163-7. PubMed Abstract | Publisher Full Text | Free Full Text | Faculty Opinions Recommendation

17. Thacher TD, Fischer PR, Pettifor JM: Vitamin D treatment in calcium-deficiency rickets: a randomised controlled trial. Arch Dis Child. 2014; 99(9): 807-11. PubMed Abstract | Publisher Full Text | Free Full Text

18. Tu MK, Levin JB, Hamilton AM, et al:: Calcium signaling in skeletal muscle development, maintenance and regeneration. Cell Calcium. 2016; 59(2-3): 91-7. PubMed Abstract | Publisher Full Text | Free Full Text

19. Peacock M: Calcium metabolism in health and disease. Clin J Am Soc Nephrol. 2010; 5 Suppl 1: S23-30. PubMed Abstract | Publisher Full Text

20. Sabbagh Y, Carpenter TO, Demay MB: Hypophosphatemia leads to rickets by impairing caspase-mediated apoptosis of hypertrophic chondrocytes. Proc Natl Acad Sci U S A. 2005; 102(27): 9637-42. PubMed Abstract | Publisher Full Text | Free Full Text

21. Aggarwal V, Seth A, Marwaha RK, et al.: Management of nutritional rickets in Indian children: a randomized controlled trial. J Trop Pediatr. 2013; 59(2): 127-33.

PubMed Abstract | Publisher Full Text

22. Girgis CM: Vitamin D and Skeletal Muscle: Emerging Roles in Development, Anabolism and Repair. Calcif Tissue Int. 2020; 106(1): 47-57. PubMed Abstract | Publisher Full Text | Faculty Opinions Recommendation 23. Girgis $\mathrm{CM}$, Clifton-Bligh RJ, Mokbel N, et al:: Vitamin D signaling regulates 
proliferation, differentiation, and myotube size in $\mathrm{C} 2 \mathrm{C} 12$ skeletal muscle cells. Endocrinology. 2014; 155(2): 347-57.

PubMed Abstract | Publisher Full Text

24. Owens DJ, Sharples AP, Polydorou I, et al:: A systems-based investigation into vitamin $\mathrm{D}$ and skeletal muscle repair, regeneration, and hypertrophy. $A m \mathrm{~J}$ Physiol Endocrinol Metab. 2015; 309(12): E1019-31. PubMed Abstract | Publisher Full Text

25. Schubert L, DeLuca HF: Hypophosphatemia is responsible for skeletal muscle weakness of vitamin D deficiency. Arch Biochem Biophys. 2010; 500(2): 157-61. PubMed Abstract | Publisher Full Text

26. Kaur T, Rush ET, Bhattacharya RK: PHOSPHATURIC MESENCHYMAL HEEL TUMOR PRESENTING WITH TUMOR-INDUCED OSTEOMALACIA. AACE Clin Case Rep. 2018; 5(2): e138-e141.

PubMed Abstract | Publisher Full Text | Free Full Text |

Faculty Opinions Recommendation

27. McCarty MF: Vitamin D status and muscle strength. Am J Clin Nutr. 2002; 76(6): 1454-5; author reply 1455-6.

PubMed Abstract | Publisher Full Text

28. Vazquez G, de Boland AR, Boland RL: 1alpha,25-dihydroxy-vitamin-D3induced store-operated $\mathrm{Ca}^{2+}$ influx in skeletal muscle cells. Modulation by phospholipase c, protein kinase c, and tyrosine kinases. J Biol Chem. 1998; 273(51): 33954-60.

PubMed Abstract | Publisher Full Text

29. Morelli S, de Boland AR, Boland RL: Generation of inositol phosphates, diacylglycerol and calcium fluxes in myoblasts treated with 1,25dihydroxyvitamin D3. Biochem J. 1993; 289(Pt 3): 675-9. PubMed Abstract | Publisher Full Text | Free Full Text

30. Girgis $\mathrm{CM}$, Clifton-Bligh RJ, Hamrick MW, et al:: The roles of vitamin D in skeletal muscle: form, function, and metabolism. Endocr Rev. 2013; 34(1): 33-83. PubMed Abstract | Publisher Full Text

31. Girgis CM, Cha KM, So B, et al.: Mice with myocyte deletion of vitamin D receptor have sarcopenia and impaired muscle function. J Cachexia Sarcopenia Muscle. 2019; 10(6): 1228-40.

PubMed Abstract | Publisher Full Text | Free Full Text

Faculty Opinions Recommendation

32. Sinha A, Hollingsworth KG, Ball S, et al:: Improving the vitamin D status of vitamin $D$ deficient adults is associated with improved mitochondrial oxidative function in skeletal muscle. J Clin Endocrinol Metab. 2013; 98(3): E509-13. PubMed Abstract | Publisher Full Text

33. Wang $\mathrm{Y}$, DeLuca HF: Is the vitamin d receptor found in muscle? Endocrinology. 2011; 152(2): 354-63.

PubMed Abstract | Publisher Full Text

34. Pike JW: Expression of the vitamin D receptor in skeletal muscle: are we there yet? Endocrinology. 2014; 155(9): 3214-8.

PubMed Abstract | Publisher Full Text | Free Full Text

35. Girgis CM, Mokbel N, Cha KM, et al.: The vitamin D receptor (VDR) is expressed in skeletal muscle of male mice and modulates 25-hydroxyvitamin D (25OHD) uptake in myofibers. Endocrinology. 2014; 155(9): 3227-37.

PubMed Abstract | Publisher Full Text | Free Full Text

36. Pojednic RM, Ceglia L, Olsson K, et al.: Effects of 1,25-dihydroxyvitamin D3 and vitamin D3 on the expression of the vitamin d receptor in human skeletal muscle cells. Calcif Tissue Int. 2015; 96(3): 256-63.

PubMed Abstract | Publisher Full Text | Free Full Text

37. Abboud M, Rybchyn MS, Ning YJ, et al:: 1,25-Dihydroxycholecalciferol (calcitriol) modifies uptake and release of 25-hydroxycholecalciferol in skeletal muscle cells in culture. J Steroid Biochem Mol Biol. 2018; 177: 109-15. PubMed Abstract | Publisher Full Text

38. Brennan-Speranza TC, Mor D, Mason RS, et al:: Skeletal muscle vitamin D in patients with end stage osteoarthritis of the knee. J Steroid Biochem Mol Biol. 2017; 173: 180-4.

PubMed Abstract | Publisher Full Text

39. Chen S, Villalta SA, Agrawal DK: FOXO1 mediates vitamin D deficiency-induced insulin resistance in skeletal muscle. J Bone Miner Res. 2016; 31(3): 585-95. PubMed Abstract | Publisher Full Text | Free Full Text

40. Pratt J, Boreham C, Ennis S, et al.: Genetic associations with aging muscle: A systematic review. Cells. 2019; 9(1): 12.

PubMed Abstract | Publisher Full Text | Free Full Text

Faculty Opinions Recommendation

41. Whitfield GK, Remus LS, Jurutka PW, et al.: Functionally relevant polymorphisms in the human nuclear vitamin $\mathrm{D}$ receptor gene. Mol Cell Endocrinol. 2001; 177(1-2): 145-59. PubMed Abstract | Publisher Full Text

42. Roth SM, Zmuda JM, Cauley JA, et al:: Vitamin D receptor genotype is associated with fat-free mass and sarcopenia in elderly men. $J$ Gerontol A Biol Sci Med Sci. 2004; 59(1): 10-5. PubMed Abstract | Publisher Full Text

43. Windelinckx A, de Mars G, Beunen G, et al:: Polymorphisms in the vitamin $D$ receptor gene are associated with muscle strength in men and women. Osteoporos Int. 2007; 18(9): 1235-42.

PubMed Abstract | Publisher Full Text

44. Hopkinson NS, Li KW, Kehoe A, et al.: Vitamin D receptor genotypes influence quadriceps strength in chronic obstructive pulmonary disease. Am J Clin Nutr. 2008; 87(2): 385-90.

PubMed Abstract | Publisher Full Text

45. Walsh S, Ludlow AT, Metter EJ, et al:: Replication study of the vitamin D receptor (VDR) genotype association with skeletal muscle traits and sarcopenia. Aging Clin Exp Res. 2016; 28(3): 435-42. PubMed Abstract | Publisher Full Text | Free Full Text

46. Xia Z, Man Q, Li L, et al.: Vitamin D receptor gene polymorphisms modify the association of serum 25-hydroxyvitamin $D$ levels with handgrip strength in the elderly in Northern China. Nutrition. 2019; 57: 202-7. PubMed Abstract | Publisher Full Text | Faculty Opinions Recommendation

47. Shokri HM, Mohamed KO, Fahmy NA, et al.: Vitamin D receptor gene polymorphism in patients with osteomalacic myopathy in Egypt. Neurol Sci. 2020.

PubMed Abstract | Publisher Full Text | Faculty Opinions Recommendation

48. C Björk A, Ribom E, Johansson G, et al.: Variations in the vitamin D receptor gene are not associated with measures of muscle strength, physical performance, or falls in elderly men. Data from MrOS Sweden. J Steroid Biochem Mol Biol. 2019; 187: 160-5.

PubMed Abstract | Publisher Full Text | Faculty Opinions Recommendation

49. Gussago C, Arosio B, Guerini FR, et al:: Impact of vitamin D receptor polymorphisms in centenarians. Endocrine. 2016; 53(2): 558-64.

PubMed Abstract | Publisher Full Text

50. Morrison NA, Yeoman R, Kelly PJ, et al:: Contribution of trans-acting factor alleles to normal physiological variability: Vitamin $D$ receptor gene polymorphism and circulating osteocalcin. Proc Natl Acad Sci U S A. 1992; 89(15): 6665-9.

PubMed Abstract | Publisher Full Text | Free Full Text

51. Fang $Y$, van Meurs JBJ, d'Alesio A, et al.: Promoter and 3'-untranslated-region haplotypes in the vitamin d receptor gene predispose to osteoporotic fracture: The rotterdam study. Am J Hum Genet. 2005; 77(5): 807-23. PubMed Abstract | Publisher Full Text | Free Full Text

52. Bozsodi A, Boja S, Szilagyi A, et al.: Muscle strength is associated with vitamin D receptor gene variants. J Orthop Res. 2016; 34(11): 2031-7. PubMed Abstract | Publisher Full Text

53. Ashcroft SP, Bass JJ, Kazi AA, et al.: The vitamin D receptor regulates mitochondrial function in C2C12 myoblasts. Am J Physiol, Cell Physiol. 2020; 318(3): C536-C541.

PubMed Abstract | Publisher Full Text | Free Full Text |

Faculty Opinions Recommendation

54. Everts HB, Berdanier CD: Regulation of mitochondrial gene expression by retinoids. IUBMB Life. 2002; 54(2): 45-9. PubMed Abstract | Publisher Full Text

55. Bischoff-Ferrari HA, Borchers M, Gudat F, et al.: Vitamin D receptor expression in human muscle tissue decreases with age. J Bone Miner Res. 2004; 19(2): 265-9.

PubMed Abstract | Publisher Full Text

56. Ceglia L, Niramitmahapanya S, da Silva Morais M, et al.: A randomized study on the effect of vitamin D supplementation on skeletal muscle morphology and vitamin D receptor concentration in older women. $J$ Clin Endocrinol Metab. 2013; 98(12): E1927-35.

2013; 98(12): E1927-35.
PubMed Abstract | Publisher Full Text | Free Full Text

57. Goltzman D: Inferences from genetically modified mouse models on the skeletal actions of vitamin D. J Steroid Biochem Mol Biol. 2015; 148: 219-24. PubMed Abstract | Publisher Full Text

58. Li YC, Amling M, Pirro AE, et al:: Normalization of mineral ion homeostasis by dietary means prevents hyperparathyroidism, rickets, and osteomalacia, but not alopecia in vitamin D receptor-ablated mice. Endocrinology. 1998; 139(10): 4391-6.

PubMed Abstract | Publisher Full Text

59. Xue $\mathrm{Y}$, Fleet $\mathrm{JC}$ : Intestinal vitamin $\mathrm{D}$ receptor is required for normal calcium and bone metabolism in mice. Gastroenterology. 2009; 136(4): 1317-27, e1-2. PubMed Abstract | Publisher Full Text | Free Full Text

60. Osima M, Borgen TT, Lukic M, et al:: Serum parathyroid hormone is associated with increased cortical porosity of the inner transitional zone at the proximal femur in postmenopausal women: The Tromsø Study. Osteoporos Int. 2018; 29(2): 421-31.

PubMed Abstract | Publisher Full Text | Faculty Opinions Recommendation

61. Zebaze R, Seeman E: Cortical bone: A challenging geography. J Bone Miner Res. 2015; 30(1): 24-9.

PubMed Abstract | Publisher Full Text

62. Tiosano D, Gepstein V: Vitamin D action: Lessons learned from hereditary 1,25dihydroxyvitamin-D-resistant rickets patients. Curr Opin Endocrinol Diabetes Obes. 2012; 19(6): 452-9. PubMed Abstract | Publisher Full Text

63. Tiosano D, Weisman Y: Reproductive history of patients with hereditary 1,25-dihydroxyvitamin D-resistant rickets. Fertil Steril. 2019; 112(1): 156-61. PubMed Abstract | Publisher Full Text | Faculty Opinions Recommendation

64. Bischoff-Ferrari HA, Dietrich T, Orav EJ, et al.: Higher 25-hydroxyvitamin D concentrations are associated with better lower-extremity function in both 
active and inactive persons aged or $=60$ y. Am J Clin Nutr. 2004; 80(3): 752-8. PubMed Abstract | Publisher Full Text

65. Wicherts IS, van Schoor NM, Boeke AJP, et al.: Vitamin D status predicts physical performance and its decline in older persons. $J$ Clin Endocrinol Metab. 2007; 92(6): 2058-65.

PubMed Abstract | Publisher Full Text

66. Visser $M$, Deeg DJH, Lips $P$ : Low vitamin $D$ and high parathyroid hormone levels as determinants of loss of muscle strength and muscle mass (sarcopenia): The Longitudinal Aging Study Amsterdam. J Clin Endocrinol Metab. 2003; 88(12): 5766-72.

PubMed Abstract | Publisher Full Text

67. Snijder MB, van Schoor NM, Pluijm SMF, et al:: Vitamin D status in relation to one-year risk of recurrent falling in older men and women. $J$ Clin Endocrinol Metab. 2006; 91(8): 2980-5

PubMed Abstract | Publisher Full Text

68. Hosseinpour F, Wikvall K: Porcine microsomal vitamin D(3) 25-hydroxylase (CYP2D25). Catalytic properties, tissue distribution, and comparison with human CYP2D6. J Biol Chem. 2000; 275(44): 34650-5. PubMed Abstract | Publisher Full Text

69. Mori R, Yokokawa T, Fujita S: Modified expression of vitamin D receptor and CYP27B1 in denervation-induced muscle atrophy. Biochem Biophys Res Commun. 2020; 529(3): 733-9.

PubMed Abstract | Publisher Full Text | Faculty Opinions Recommendation

70. Allen RM, Cureton TK: Effect of ultraviolet radiation on physical fitness. Arch Phys Med Rehabil. 1945; 26: 641-4. PubMed Abstract

71. Co La Puente Yagüe M, Collado Yurrita L, Ciudad Cabañas MJ, et al:: Role of vitamin $D$ in athletes and their performance: Current concepts and new trends. Nutrients. 2020; 12(2): 579.

PubMed Abstract | Publisher Full Text | Free Full Text |

Faculty Opinions Recommendation

72. Close GL, Leckey J, Patterson $\mathrm{M}$, et al: The effects of vitamin $\mathrm{D}(3)$ supplementation on serum total $250 \mathrm{HD}$ concentration and physical performance: A randomised dose-response study. Br J Sports Med. 2013; 47(11): 692-6.

PubMed Abstract | Publisher Full Text

73. Close GL, Russell J, Cobley JN, et al: Assessment of vitamin D concentration in non-supplemented professional athletes and healthy adults during the winter months in the UK:Implications for skeletal muscle function. J Sports Sci. 2013; 31(4): 344-53.

PubMed Abstract | Publisher Full Text

74. $\mathrm{Han} Q$, Li X, Tan Q, et al.: Effects of vitamin D3 supplementation on serum 25(OH)D concentration and strength in athletes: A systematic review and meta-analysis of randomized controlled trials. J Int Soc Sports Nutr. 2019; 16(1): 55.

PubMed Abstract | Publisher Full Text | Free Full Text |

Faculty Opinions Recommendation

75. Książek A, Zagrodna A, Słowińska-Lisowska M: Vitamin D skeletal muscle function and athletic performance in athletes-A narrative review. Nutrients. 2019; 11(8): 1800.

PubMed Abstract | Publisher Full Text | Free Full Text |

Faculty Opinions Recommendation

76. Farrokhyar F, Sivakumar G, Savage K, et al:: Effects of vitamin D supplementation on serum 25-hydroxyvitamin D concentrations and physical performance in athletes: A systematic review and meta-analysis of randomized controlled trials. Sports Med. 2017; 47(11): 2323-2339. PubMed Abstract | Publisher Full Text

77. Antoniak $\mathrm{AE}$, Greig $\mathrm{CA}$ : The effect of combined resistance exercise training and vitamin D3 supplementation on musculoskeletal health and function in older adults: A systematic review and meta-analysis. BMJ Open. 2017; 7(7): e014619. PubMed Abstract | Publisher Full Text | Free Full Text

78. Rosendahl-Riise H, Spielau U, Ranhoff AH, et al.: Vitamin D supplementation and its influence on muscle strength and mobility in community-dwelling older persons: A systematic review and meta-analysis. J Hum Nutr Diet. 2017; 30(1): 3-15.

PubMed Abstract | Publisher Full Text | Free Full Text

79. Tomlinson PB, Joseph C, Angioi M: Effects of vitamin D supplementation on upper and lower body muscle strength levels in healthy individuals. A systematic review with meta-analysis. J Sci Med Sport. 2015; 18(5): 575-80. PubMed Abstract | Publisher Full Text

80. Remelli F, Vitali A, Zurlo A, et al:: Vitamin D deficiency and sarcopenia in older persons. Nutrients. 2019; 11(12): 2861 PubMed Abstract | Publisher Full Text | Free Full Text | Faculty Opinions Recommendation

81. Glerup H, Mikkelsen K, Poulsen L, et al.: Hypovitaminosis D myopathy without biochemical signs of osteomalacic bone involvement. Calcif Tissue Int. 2000; 66(6): 419-24.

PubMed Abstract | Publisher Full Text

82. Moreira-Pfrimer LDF, Pedrosa MAC, Teixeira L, et al:: Treatment of vitamin D deficiency increases lower limb muscle strength in institutionalized older people independently of regular physical activity: A randomized double-blind controlled trial. Ann Nutr Metab. 2009; 54(4): 291-300.

PubMed Abstract | Publisher Full Text

83. Muir SW, Montero-Odasso M: Effect of vitamin D supplementation on muscle strength, gait and balance in older adults: A systematic review and metaanalysis. J Am Geriatr Soc. 2011; 59(12): 2291-300.

PubMed Abstract | Publisher Full Text

84. Stockton KA, Mengersen K, Paratz JD, et al:: Effect of vitamin D supplementation on muscle strength: A systematic review and meta-analysis. Osteoporos Int. 2011; 22(3): 859-71.

PubMed Abstract | Publisher Full Tex

85. Beaudart C, Buckinx F, Rabenda V, et al:: The effects of vitamin D on skeletal muscle strength, muscle mass, and muscle power: A systematic review and meta-analysis of randomized controlled trials. J Clin Endocrinol Metab. 2014; 99(11): 4336-45

PubMed Abstract | Publisher Full Text

86. Abshirini M, Mozaffari H, Kord-Varkaneh $\mathrm{H}$, et al:: The effects of vitamin D supplementation on muscle strength and mobility in postmenopausal women: A systematic review and meta-analysis of randomised controlled trials. $J$ Hum Nutr Diet. 2020; 33(2): 207-21.

PubMed Abstract | Publisher Full Text | Faculty Opinions Recommendation

87. Bischoff-Ferrari HA, Dietrich T, Orav EJ, et al:: Positive association between 25hydroxy vitamin $D$ levels and bone mineral density: A population-based study of younger and older adults. Am J Med. 2004; 116(9): 634-9.

PubMed Abstract | Publisher Full Text

88. Kuchuk NO, Pluijm SMF, van Schoor NM, et al.: Relationships of serum 25hydroxyvitamin $D$ to bone mineral density and serum parathyroid hormone and markers of bone turnover in older persons. J Clin Endocrinol Metab. 2009; 94(4): 1244-50.

PubMed Abstract | Publisher Full Text

89. Winzenberg T, Powell S, Shaw KA, et al: Effects of vitamin D supplementation on bone density in healthy children: Systematic review and meta-analysis. BMJ. 2011; 342: c7254

PubMed Abstract | Publisher Full Text | Free Full Text

90. Dunstan CR: Vitamin D supplements and bone mineral density. Lancet. 2014; 383(9925): 1292

PubMed Abstract | Publisher Full Text

91. Reid IR, Bolland MJ, Grey A: Effects of vitamin D supplements on bone mineral density: A systematic review and meta-analysis. Lancet. 2014; 383(9912): 146-55.

PubMed Abstract | Publisher Full Text | Faculty Opinions Recommendation

92. Lips $P$, van Schoor NM: The effect of vitamin $D$ on bone and osteoporosis. Best Pract Res Clin Endocrinol Metab. 2011; 25(4): 585-91.

PubMed Abstract | Publisher Full Text

93. Reid IR, Horne AM, Mihov B, et al.: Effect of monthly high-dose vitamin D on bone density in community-dwelling older adults substudy of a randomized controlled trial. $J$ Intern Med. 2017; 282(5): 452-60.

PubMed Abstract | Publisher Full Text

94. Reid IR, Bolland MJ, Grey A: Vitamin D supplements and bone mineral density - Authors' reply. Lancet. 2014; 383(9925): 1293-4.

PubMed Abstract | Publisher Full Text

95. Munns CF, Shaw N, Kiely M, et al.: Global consensus recommendations on prevention and management of nutritional rickets. J Clin Endocrinol Metab. 2016; 101(2): 394-415.

PubMed Abstract | Publisher Full Text | Free Full Text

96. Lips $\mathrm{P}$, Netelenbos JC, Jongen MJ, et al.: Histomorphometric profile and vitamin d status in patients with femoral neck fracture. Metab Bone Dis Relat Res. 1982; 4(2): 85-93.

PubMed Abstract | Publisher Full Text

97. Priemel M, von Domarus C, Klatte TO, et al:: Bone mineralization defects and vitamin $D$ deficiency: Histomorphometric analysis of iliac crest bone biopsies and circulating 25-hydroxyvitamin D in 675 patients. J Bone Miner Res. 2010; 25(2): 305-12.

PubMed Abstract | Publisher Full Text

98. Holick MF, Binkley NC, Bischoff-Ferrari HA, et al:: Guidelines for preventing and treating vitamin $\mathrm{D}$ deficiency and insufficiency revisited. J Clin Endocrino Metab. 2012; 97(4): 1153-8.

PubMed Abstract | Publisher Full Text

99. Bischoff-Ferrari HA, Dawson-Hughes B, Staehelin HB, et al.: Fall prevention with supplemental and active forms of vitamin D: A meta-analysis of randomised controlled trials. BMJ. 2009; 339: b3692.

PubMed Abstract | Publisher Full Text | Faculty Opinions Recommendation

100. Cameron ID, Gillespie LD, Robertson MC, et al: Interventions for preventing falls in older people in care facilities and hospitals. Cochrane Database Syst Rev. 2012; 12: CD005465.

PubMed Abstract | Publisher Full Text

101. Gillespie LD, Robertson MC, Gillespie WJ, et al:: Interventions for preventing falls in older people living in the community. Cochrane Database Syst Rev. 2012: (9): CD007146.

PubMed Abstract | Publisher Full Text 
102. LeBlanc ES, Chou R: Vitamin D and falls-fitting new data with current guidelines. JAMA Intern Med. 2015; 175(5): 712-3. PubMed Abstract | Publisher Full Text

103. Bolland MJ, Grey A, Gamble GD, et al:: Vitamin D supplementation and falls: A trial sequential meta-analysis. Lancet Diabetes Endocrinol. 2014; 2(7): 573-80. PubMed Abstract | Publisher Full Text

104. Pfeifer M, Begerow B, Minne HW, et al.: Effects of a long-term vitamin D and calcium supplementation on falls and parameters of muscle function in community-dwelling older individuals. Osteoporos Int. 2009; 20(2): 315-22. PubMed Abstract | Publisher Full Text

105. CYao P, Bennett D, Mafham M, et al:: Vitamin D and Calcium for the Prevention of Fracture: A Systematic Review and Meta-analysis. JAMA Netw Open. 2019; 2(12): e1917789.

PubMed Abstract | Publisher Full Text | Free Full Text | Faculty Opinions Recommendation

106. Avenell A, Gillespie WJ, Gillespie LD, et al.: Vitamin D and vitamin D analogues for preventing fractures associated with involutional and post-menopausal osteoporosis. Cochrane Database Syst Rev. 2009; (3): CD000227. PubMed Abstract | Publisher Full Text

107. IOM, Institute of Medicine (IOM): Dietary Reference Intakes for Calcium and Vitamin D. Washington, DC: National Academies Press. 2011. PubMed Abstract | Publisher Full Text

108. Boonen S, Lips $\mathrm{P}$, Bouillon R, et al:: Need for additional calcium to reduce the risk of hip fracture with vitamin d supplementation: Evidence from a comparative metaanalysis of randomized controlled trials. J Clin Endocrinol Metab. 2007; 92(4): 1415-23. PubMed Abstract | Publisher Full Text

109. Bouillon R, van Schoor NM, Gielen E, et al.: Optimal vitamin D status: A critical analysis on the basis of evidence-based medicine. J Clin Endocrinol Metab. 2013; 98(8): E1283-304. PubMed Abstract | Publisher Full Text

110. Gallagher JC, Sai A, Templin T, et al:: Dose response to vitamin D supplementation in postmenopausal women: A randomized trial. Ann Intern Med. 2012; 156(6): 425-37.

PubMed Abstract | Publisher Full Text

111. Bolland MJ, Grey A, Avenell A: Effects of vitamin D supplementation on musculoskeletal health: a systematic review, meta-analysis, and tria sequential analysis. Lancet Diabetes Endocrinol. 2018; 6(11): 847-58. PubMed Abstract | Publisher Full Text | Faculty Opinions Recommendation

112. Smith $\mathrm{H}$, Anderson $\mathrm{F}$, Raphael $\mathrm{H}$, et al.: Effect of annual intramuscular vitamin $\mathrm{D}$ on fracture risk in elderly men and women--a population-based, randomized, double-blind, placebo-controlled trial. Rheumatology (Oxford). 2007; 46(12): 1852-7.

PubMed Abstract | Publisher Full Text

113. Sanders KM, Stuart AL, Williamson EJ, et al:: Annual high-dose oral vitamin D and falls and fractures in older women: a randomized controlled trial. JAMA. 2010; 303(18): 1815-22.

PubMed Abstract | Publisher Full Text

114. Nowson CA, McGrath JJ, Ebeling PR, et al:: Vitamin D and health in adults in Australia and New Zealand: a position statement. [press release]. Med J Aust. 2012; 196(11): 686-7 PubMed Abstract | Publisher Full Text

115. Neme A, Seuter S, Malinen M, et al:: In vivo transcriptome changes of human white blood cells in response to vitamin D. J Steroid Biochem Mol Biol. 2019; 188: 71-6.

PubMed Abstract | Publisher Full Text | Faculty Opinions Recommendation

116. Kiebzak GM, Neal KM, Hosseinzadeh P, et al.: Pitfalls with Vitamin D
Research in Musculoskeletal Disorders and Recommendations on How to Avoid Them. J Clin Res Pediatr Endocrinol. 2019; 11(3): 220-6. PubMed Abstract | Publisher Full Text | Free Full Text | Faculty Opinions Recommendation

117. Autier P, Boniol M, Pizot C, et al.: Vitamin D status and ill health: systematic review. Lancet Diabetes Endocrinol. 2014; 2(1): 76-89. PubMed Abstract | Publisher Full Text | Faculty Opinions Recommendation

118. Martineau AR, Jolliffe DA, Hooper RL, et al:: Vitamin D supplementation to prevent acute respiratory tract infections: systematic review and metaanalysis of individual participant data. BMJ. 2017; 356: i6583. PubMed Abstract | Publisher Full Text | Free Full Text | Faculty Opinions Recommendation

119. Jolliffe DA, Greenberg L, Hooper RL, et al:: Vitamin D supplementation to prevent asthma exacerbations: a systematic review and meta-analysis of individual participant data. Lancet Respir Med. 2017; 5(11): 881-90. PubMed Abstract | Publisher Full Text | Free Full Text

120. Durup D, Jørgensen $\mathrm{HL}$, Christensen J, et al.: A reverse J-shaped association of all-cause mortality with serum 25 -hydroxyvitamin $D$ in general practice: the CopD study. J Clin Endocrinol Metab. 2012; 97(8): 2644-52. PubMed Abstract | Publisher Full Text | Faculty Opinions Recommendation

121. Sempos CT, Durazo-Arvizu RA, Dawson-Hughes B, et al.: Is there a reverse $\mathrm{J}$-shaped association between 25 -hydroxyvitamin $\mathrm{D}$ and all-cause mortality? Results from the U.S. nationally representative NHANES. J Clin Endocrinol Metab. 2013; 98(7): 3001-9. Metab. 2013; 98(7): 3001-9.
PubMed Abstract | Publisher Full Text | Free Full Text | Faculty Opinions Recommendation

122. Hagström E, Hellman $\mathrm{P}$, Larsson TE, et al:: Plasma parathyroid hormone and the risk of cardiovascular mortality in the community. Circulation. 2009; 119(21): 2765-71

PubMed Abstract | Publisher Full Text

123. Rejnmark L, Avenell A, Masud T, et al.: Vitamin D with calcium reduces mortality: Patient level pooled analysis of 70,528 patients from eight major vitamin D trials. J Clin Endocrinol Metab. 2012; 97(8): 2670-81. PubMed Abstract | Publisher Full Text | Free Full Text | Faculty Opinions Recommendation

124. Bjelakovic G, Gluud LL, Nikolova D, et al.: Vitamin D supplementation for prevention of cancer in adults. Cochrane Database Syst Rev. 2014; (6): CD007469.

PubMed Abstract | Publisher Full Text

125. Chowdhury R, Kunutsor S, Vitezova A, et al:: Vitamin D and risk of cause specific death: Systematic review and meta-analysis of observational cohort and randomised intervention studies. BMJ. 2014; 348: g1903. PubMed Abstract | Publisher Full Text | Free Full Text | Faculty Opinions Recommendation

126. Cauley JA, Danielson ME, Boudreau R, et al:: Serum 25-hydroxyvitamin $D$ and clinical fracture risk in a multiethnic cohort of women: The Women's Health Initiative (WHI). J Bone Miner Res. 2011; 26(10): 2378-88. PubMed Abstract | Publisher Full Text | Free Full Text | Faculty Opinions Recommendation

127. Binkley N, Krueger D, Cowgill CS, et al:: Assay variation confounds the diagnosis of hypovitaminosis D: A call for standardization. J Clin Endocrinol Metab. 2004; 89(7): 3152-7. PubMed Abstract | Publisher Full Text

128. Statistics A.B.O: Australian Health Survey: Biomedical Results for Nutrients. 2011-12: Australian Bureau of Statistics. 2011-12 [cited 2018 13th May]. Reference Source 